\title{
Pengaruh Penggunaan Media Powerpoint Terhadap Minat Belajar Bahasa Arab Siswa
}

\author{
Elvia Susanti \\ Universitas Muhammadiyah Sumatera Barat \\ elviasusanti@gmail.com \\ Mahyudin Ritonga \\ Universitas Muhammadiyah Sumatera Barat \\ mahyudinritonga@gmail.com \\ Bambang \\ Universitas Muhammadiyah Sumatera Barat \\ bambangelminda@gmail.com
}

\begin{abstract}
This research aims to determine the influence of power point media towards students' interest in learning Arabic, this goal is based on the problem of low interest students in learning Arabic, the low motivation is according to the hypothesis of the researcher is caused by the inability of teachers to use media that is already familiar with students such as power points. The study used quantitative methods with a test design of the use of PowerPoint on learning in the classroom and seeing its high influence on the students ' Arab learning interests. Data sources of all X-grade students and data analysis techniques using simple recreation assisted with SPSS version 24. Analysis of research data showed: 1) the PowerPoint Medium on Arabic language learning in the high category, evidenced by the median 82.5 2) interest in learning Arabic students was in categories with median 61.7. 3) There is a significant influence of $25.7 \%$ by variable $\mathrm{X}$ to variable $\mathrm{Y}$, with a value of sig 0.008 and R Square 0.257 .
\end{abstract}

Keywords: learning media, interests, Arabic language, improvement

\begin{abstract}
Abstrak
Penelitian ini bertujuan untuk mengetahui pengaruh media power point terhadap minat siswa mempelajari bahasa Arab, tujuan ini didasarkan pada permasalahan rendahnya minat siswa dalam mempelajari bahasa Arab, rendahnya motivasi tersebut menurut hipotesis peneliti salah satunya disebabkan oleh ketidakmampuan
\end{abstract}


guru dalam menggunakan media yang sudah akrab dengan siswa seperti power point. Penelitian ini menggunakan metode kuantitatif dengan rancangan uji pengaruh penggunaan powerpoint pada pembelajaran di kelas dan melihat tingginya pengaruhnya terhadap minat belajar bahasa Arab siswa. Sumber data semua siswa kelas X dan teknik analisis data menggunakan rekresi sederhana yang dibantu dengan SPSS versi 24. Analisis data penelitian menunjukkan: 1) media powerpoint pada pembelajaran bahasa Arab dalam kategori tinggi, yang dibuktikan dengan median 82,5 2) minat belajar bahasa Arab siswa berada pada kategori dengan median 61,7. 3) Terdapat pengaruh yang signifikan sebesar $25,7 \%$ oleh variabel $X$ terhadap variabel $\mathrm{Y}$, dengan nilai sig 0,008 dan $\mathrm{R}$ square 0,257 .

Kata Kunci: media pembelajaran, minat, bahasa Arab, peningkatan

\section{Pendahuluan}

Salah satu yang harus menjadi pemikiran guru ialah bagaimana menjadikan pelajaran disenangi serta diminati oleh peserta didik, Zulhannan mengatakan bahwa bahasa Arab pada zaman sekarang tidak termasuk pelajaran yang disukai oleh siswa, sejumlah siswa baik pada lembaga formal, informal maupun nonformal memandangnya sebagai pelajaran yang menakutkan, ${ }^{1}$ sulit dan membosankan. ${ }^{2}$ Kedua pandangan di atas juga sesuai dengan hasil observasi penulis sebelum melakukan penelitian di Madrasah Aliyah Muhammadiyah Sulit Air. Berdasarkan observasi penulis, pembelajaran bahasa Arab siswa kelas X MAM Sulit Air khususnya masih dikategorikan kurang diminati siswa. Setiap belajar bahasa Arab semangat para siswa menurun, ada juga siswa yang tidak mengerjakan tugas bahasa Arab yang telah diberikan bahkan ada siswa yang sengaja keluar pada saat jam belajar bahasa Arab.

Jika dilihat dari urgensi minat dan motivasi maka dapat dikatakan tidak akan pernah seseorang meraih keberhasilan tanpa diawaali dengan kehadiran motivasi dalam dirinya. ${ }^{3}$ Sebagai langkah untuk meminimalisir ketidaksukaan peserta didik terhadap pelajaran bahasa Arab guru harus melakukan inovasi

1 Zulhannan, Teknik Pembelajaran Bahasa Arab Interaktif (Jakarta: PT. Raja Grafindo, 2014).

2 Vivi Maimunah, Zaim El Mubarok, and Ahmad Miftahuddin, 'KIA (Kitabah Itu Asyik): Pengembangan Multimedia Berbasis Adobe Falsh Professional CS6 Pada Keterampilan Menulis Untuk Siswa Kelas X MA', LISANUL ARAB Journal of Arabic Learning and Teaching, 7.1 (2018), $54-62$.

${ }^{3}$ Jawad Karaghanh and others, 'Al-'Alaqah Bayn Hafiz Al-Ta'allum Wa Maharah AlMuhadatsah Min Khilal Al-Taqyim Al-Dzaty Li Mudarris Al-Lughah Al-'Arabiyyah', Majallab Kulliyah Al-Tarbiyyah Al-Asasiyyah Li Al-'Ulum Al-Tarbawiyyah Wa Al-Insaniyyah, 43.1 (2019), 754 64. 
seperti inovasi metode ${ }^{45}$ media ${ }^{678}$, strategi. $^{9}$ Tugas guru sebagai inovator ${ }^{10}$ seharusnya mampu melakukan inovasi agar bahasa Arab dipandang sebagai pelajaran yang menyenangkan dan mudah sehingga peserta didik dimudahkan untuk memahami materi yang disampaikan. ${ }^{11}$ Di antara langkah yang dapat ditempuh guru dalam mewujudkan suasana pembelajaran yang menyenangkan serta tidak membosankan ialah penggunaan media yang tepat. ${ }^{12}$ Selain penggunaan media banyak peran lain yang dapat ditempuh oleh guru dalam upaya peningkatan minat serta motivasi mempelajari bahasa Arab di kalangan siswa. $^{13}$

Berkaitan dengan media pembelajaran tentu banyak jenisnya yang dapat digunakan, seperti media visual, ${ }^{14}$ audio, audio visual ${ }^{15},{ }^{16}$, salah satu media yang mudah dan simple untuk digunakan ialah powerpoint. Media ini dapat

${ }^{4}$ Asnul Uliyah and Zakiyah Isnawati, 'Metode Permainan Edukatif Dalam Pembelajaran Bahasa Arab', Shaut Al-'Arabiyah, 7.1 (2019), 31-43 <https://doi.org/10.24252/saa.v1i1.9375>.

${ }^{5}$ Muhammad Jafar Shodiq, 'Metode Pembeelajaran Bahasa Arab Aktif-Inovatif Berbasis Multiple Intelligences', Al Mahara Jurnal Pendidikan Babasa Arab, 4.1 (2018), 125-48 $<$ https://doi.org/10.1093/gao/9781884446054.article.t060170>.

6 Nanang Joko Purwanto, 'Lagu Sebagai Media Pembelajaran Tata Bahasa Arab (Nahwu)', Mabarat: Jurnal Pendidikan Bahasa Arab, 1.1 (2018), 1-13 <https://doi.org/10.18196/mht.111>.

7 Jepri Nugrawiyati, 'Media Audio-Visual Dalam Pembelajaran Bahasa Arab', ElWasathiya: Jurnal Studi Agama, 6.1 (2018), $<$ https://doi.org/10.24090/insania.v14i3.360>.

${ }^{8}$ Yufi Mohammad Nasrullah, 'Atsar Istikhdam Al-Wasa'il Al-Ta'limiyyah Fi Ta'lim AlLughah Al-'Arabiyyah Fi Jami’ah Indunisiya Al-Tarbawiyyah Bi Jazirah Jawa Al-Ghorbiyyah', Jurnal Al-Bayan, 9.1 (2017), 17-30.

9 Ahmad Arifin, 'Peranan Permainan Bahasa Dalam Proses Kegiatan Belajar Mengajar Mata Pelajaran Bahasa Arab', Jurnal An Nabighoh, 19.2 (2017), 302-18.

${ }^{10}$ I Putu Suardipa, 'Guru Sebagai Agen Inovator Berbasis Higher Order Thinking Skills', Purwadita: Jurnal Agama Dan Budaya, 2.2 (2018), 73-83.

11 Fatma Y. Al-Busaidi, 'Arabic in Foreign Language Programmes: Difficulties and Challenges', Journal of Educational and Psychological Studies JJEPS], 9.4 (2015), 701-17 $<$ https://doi.org/10.24200/jeps.vol9iss4pp701-717>.

12 Azhari Azhari, 'Peran Media Pendidikan Dalam Meningkatkan Kemampuan Bahasa

Arab Siswa Madrasah', Jurnal Ilmiah Didaktika, 16.1 (2015), 43-60 $<$ https://doi.org/10.22373/jid.v16i1.586>.

13 Achmad Tito Rusady, 'Dawafi' Al-Thullab Fi Ta'allum Al-Lughah Al-'Arabiyyah Wa Dawr Al-Mu'allim Fi Tarqiyatiha', Jurnal Izdihar: Journal of Arabic Language Teaching, Linguistics, and Literature, 1.1 (2018), 65-78.

${ }^{14}$ Iranada Laraswati and Suhartono, 'The Use of Visual Media in Teaching Writing', English-EDU Journal of English Teaching and Research, 1.1 (2016), 37-43.

${ }^{15}$ Siti Mahmudah, 'Media Pembelajaran Bahasa Arab', An Nabighoh Jurnal Pendidikan Dan Pembelajaran Bahasa Arab, 20.1 (2018), 129-38 <https://doi.org/10.32332/annabighoh.v20i01.1131>.

${ }^{16}$ Syarifuddin and Muadip, 'Pengaruh Penggunaan Media Audio Visual Terhadap Hasil Belajar Siswa Kelas X Bahasa SMA Al-Ashriyyah Nurul Iman Parung-Bogor', Jurnal Educate, 1.1 (2016), 77-102. 
dimanfaatkan setiap pendidikan dalam menyampaikan materi pembelajaran, sehingga pikiran, perasaan, pengamatan, pendengaran peserta didik dapat terangsang guna lebih serius dalam mengikuti proses pembelajaran. Powerpoint dapat dimodifikasi oleh pengguna untuk lebih menarik bagi audiens baik dari aspek tampilan, warna, maupun suaranya.

Berbagai hasil penelitian menunjukkan adanya manfaat penggunaan media powerpoint dalam pembelajaran, ${ }^{17}$ seperti peningkatan kualitas proses pembelajaran, kualitas hasil belajar ${ }^{18}$, motivasi belajar ${ }^{19}$. Sejalan dengan hal itu, pembelajaran bahasa Arab di Madrasah Aliyah Muhammadiyah Sulit Air terlihat kurang diminati peserta didik, pernyataan ini didasarkan pada hasil observasi terhadap proses belajar mengajar di sana, hasil pengamatan tersebut terlihat bahwa banyak peserta didik yang keluar pada saat pelajaran berlangsung, begitu juga tidak sedikit di antara peserta didik yang asyik bercerita dengan temannya sehingga menyebabkan suasana belajar tidak kondusif.

Kondisi yang demikian tidak bisa dipisahkan dari berbagai aspek yang terkait dengan pembelajaran seperti halnya media pembelajaran. Hasil analisis sementara penulis terhadap kondisi demikian ialah peserta didik pantas tidak punya motivasi dalam mengikuti pelajaran bahasa Arab, karena gurunya tidak menggunakan media yang lebih menarik bagi peserta didik, guru hanya mengandalkan papan tulis dan sumber belajar, pada sisi lain peserta didik sudah sangat akrab dengan berbagai media yang bersifat teknologi.

Terkait dengan realita di atas, penulis tertarik melakukan kajian terhadap penggunaan media powerpoint dan pengaruhnya terhadap peningkatan minat belajar bahasa Arab, karena minat belajar tidak hanya ditentukan oleh internal peserta didik melainkan juga dapat dipengaruhi aspek di luar dirinya. Oleh karena itu, permaslahan ini akan diteliti dan hasilnya kemudian dituangkan dalam bentuk artikel. Penelitian ini difokuskan pada 1) Deskripsi penggunaan Media powerpoint, 2) Deskripsi minat peserta didik terhadap pelajaran Bahasa Arab, kedua aspek ini akan menggambarkan tingkat keterpengaruhan penggunaan media powerpoint terhadap minat mempelajari bahasa Arab.

Penelitian ini menggunakan metode kuantitatif, yakni sebuah penelitian yang sengaja dirancang untuk mengetahui pengaruh sebuah variabel terhadap variabel lain, variabel yang dimaksud adalah pengaruh penggunaan media power point terhadap minat mempelajari bahasa Arab. Sumber data penelitian ini ialah

${ }^{17}$ Numr Samiyah, 'Dawr Al-Wasa'il Al-Ta'limiyyah Al-Haditsah Fi Tahsin Naw'iyah AlTa’'lim Bi Al-Marhalah Al-Tsanawiyyah' (Jami’ah al-'Araby bin Mahidy, 2015).

${ }_{18}$ Nurhidayati, 'Media Power Point Dan Pemanfaatannya Dalam Proses Pembelajaran Bahasa Arab', in Konferensi Nasional Bahasa Arab V, 2019, LIII, 463-70.

19 Nia Kurnia, Deni Darmawan, and Maskur Maskur, 'Efektivitas Pemanfaatan Multimedia Pembelajaran Berbantuan Ispring Dalam Meningkatkan Motivasi Dan Hasil Belajar Pada Mata Pelajaran Bahasa Arab', Teknologi Pembelajaran, 3.1 (2018), 451-61 $<$ https://doi.org/10.31980/TP.V3I1.158>. 
siswa kelas X MAM Sulit Air, teknik pengambilan sampel ialah total sampling, yakni semua siswa kelas $\mathrm{X}$, hal ini dikarenakan jumlah populasi yang kecil memungkinkannya untuk dijadikan semuanya menjadi sampel yakni 28 (dua puluh delapan) orang, teknik pengumpulan data ialah angket. Teknik analisis data pada penelitian ini dilakukan berbagai uji, yang meliputi uji validitas, uji relibialitas, normalitas, homogenitas dan uji hipotesis, analisis data tersebut dilakukan dengan bantuan program SPSS versi 24.

\section{Hasil dan Pembahasan}

\section{Deskriptif Penggunaan Media Powerpoint}

Pembelajaran bahasa Arab menggunakan powerpoint kelas X MAM Sulit Air dapat dihitung dan digambarkan melalui hasil evaluasi dari belajar yang telah dilakukan ketika eksperimen. Rumus yang digunakan dalam mengklasifikasikan data penggunaan media powerpoint ialah diawali dengan pencarian nilai siswa paling tinggi dan paling rendah, sementara untuk menetapkan skala interval nilai paling tinggi tersebut dikurangi oleh nilai paling rendah yang kemudian ditambah satu, hasil pengurangan dan penambahan tersebut kemudian dibagi empat dengan kategori ST, T, R dan SR. Rumus yang dimaksud ialah sebagaimana berikut ini:

$$
\begin{aligned}
\text { Skala Interval } & =\frac{\text { skor tertinggi }- \text { skor terendah }+1}{\text { kelas interval }} \\
& =\frac{95-70+1}{4} \\
& =\frac{26}{4} \\
& =6,5=7
\end{aligned}
$$

Berdasarkan teknik tersebut diperoleh skala interval sebagai berikut:

$$
\begin{array}{ll}
89-95 & : \text { Sangat Tinggi } \\
82-88 & : \text { Tinggi } \\
75-81 & : \text { Rendah } \\
68-74 & : \text { Sangat Rendah }
\end{array}
$$

Distribusi frekuensi pembelajaran bahasa Arab menggunakan Powerpoint dapat digambarkan sebagaimana pada tabel 1 di bawah ini:

Tabel 1. Penggunaan Powerpoint dalam Pembelajaran Bahasa Arab

\begin{tabular}{|c|c|c|c|}
\hline Klasifikasi & Interval & Frekuensi & Persentase \\
\hline Sangat Tinggi & $89-95$ & 10 & $38,5 \%$ \\
\hline Tinggi & $82-88$ & 5 & $19,2 \%$ \\
\hline Rendah & $75-81$ & 8 & $30,8 \%$ \\
\hline Sangat Rendah & $68-74$ & 3 & $11,5 \%$ \\
\hline
\end{tabular}


Sesuai dengan data pada tabel $1 \mathrm{di}$ atas dapat dideskripsikan bahwa terdapat 10 siswa atau 38,5\% yang meraih nilai antara 89-95 dan termasuk pada klasifikasi sangat tinggi. Sementara 5 orang siswa atau 19,2\% mendapatkan nilai antara 82-88 pada klasifikasi tinggi dengan persentase 19,2\%. Terdapat 8 orang atau 30,8\% peserta didik yang meraih nilai anatara 75-81 pada klasifikasi rendah dengan. Sementara siswa yang mendapatkan nilai pada klasifikasi sangat rendah ialah sebanyak 3 orang atau 11,5\%.

Setelah dilakukan penjumlahan seluruh nilai siswa didapatkan mean sebesar 82,5. Perolehan angka ini masuk dalam kategori tinggi yakni berada dalam interval 82-88. Data ini menunjukkan bahwa rerata penggunaan media powerpoint kelas X Madrasah Aliyah Muhammadiyah Sulit Air tergolong kepada klasifikasi Tinggi.Untuk lebih jelasnya gambaran pembelajaran bahasa Arab menggunakan powerpoint kelas X Madrasah Aliyah Muhammadiyah Sulit Air dapat dilihat pada histogram di bawah ini:

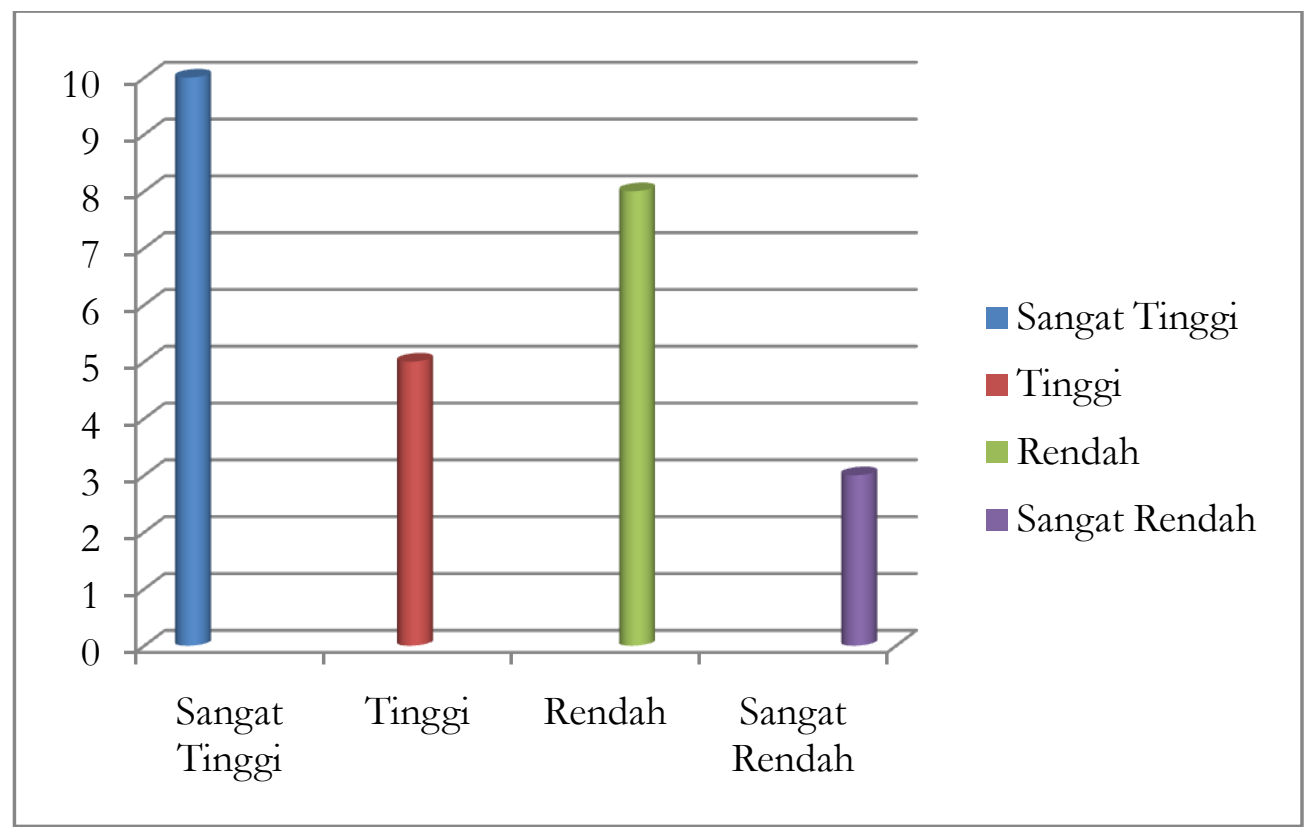

\section{Gambar 1. Histogram Pembelajaran Bahasa Arab dengan Media Power Point}

Histogram di atas memberikan pemahaman bahwa penggunaan media powerpoint dalam belajar bahasa Arab kelas X Madrasah Aliyah Muhammadiyah Sulit Air tergolong pada klasifikasi Tinggi.

\section{Deskriptif Minat Belajar Bahasa Arab Siswa}

Keinginan mempelajari bahasa Arab di kalangan siswa kelas X Madrasah Aliyah Muhammadiyah Sulit Air diketahui berdasarkan jawaban siswa terhadap kuisioner. Langkah yang peneliti lakukan dalam menentukan klasifikasi data 
terhadap aspek ini ialah mencari terlebih dahulu nilai tertinggi dan terendah, dan untuk menentukan interval rumus yang digunakan ialah nilai tertinggi tersebut dikurangi nilai terendah yang kemudian ditambah satu, hasil pengurangan dan penambahan tersebut kemudian dielompokkan menjadi empat kategor yakni SB, B, KB dan TB. Untuk lebih jelasnya dapat dicermati melalui rumus:

$$
\begin{aligned}
\text { Skala Interval }=\frac{\text { skor tertinggi }- \text { skor terendah }+1}{\text { kelas interval }} \\
=\frac{75-42+1}{4} \\
=\frac{34}{4}=8,5=9
\end{aligned}
$$

Berdasarkan teknik tersebut diperoleh skala interval sebagai berikut:

$67-75$ : Sangat Baik

58 - 66 : Baik

$49-57$ : Kurang Baik

40 - 48 : Tidak Baik

Distribusi frekuensi minat peserta didik terhadap pelajaran bahasa Arab dituangkan dalam tabel 2:

Tabel 2 Minat Peserta Didik terhadap Pelajaran Bahasa Arab

\begin{tabular}{|c|c|c|c|}
\hline Klasifikasi & Interval & Frekuensi & Persentase \\
\hline Sangat Baik & $67-75$ & 9 & $34,6 \%$ \\
\hline Baik & $58-66$ & 10 & $38,5 \%$ \\
\hline Kurang Baik & $49-57$ & 5 & $19,2 \%$ \\
\hline Tidak Baik & $40-48$ & 2 & $7,7 \%$ \\
\hline
\end{tabular}

Sesuai dengan data pada tabel di atas dapat diinterpretasikan bahwa terdapat 9 orang siswa atau 34,6\% yang merasakan penggunaan powerpoint menjadikan minatnya sangat baik dalam mempelajari bahasa Arab. Sedangkan 10 orang siswa atau setara dengan 38,5\% merasakan penggunaan media power point menjadikan minatnya baik dalam mengikuti pelajaran bahasa Arab. Selanjutnya didapat 5 orang informan atau 19,2\% menyatakan minatnya kurang baik walaupun guru menggunakan media power point dalam kegiatan pembelajaran bahasa Arab. Informan lain yang berjumlah 2 siswa atau 7,7\% menganggap minat mempelajari bahasa Arab tetap tidak baik walaupun guru sudah menggunakan media power point.

Setelah dilakukan penjumlahan seluruh skor didapatkan mean sebesar 61,7. Perolehan rerata ini masuk dalam kategori baik yaitu berada pada skor antara 58-66. Perolehan ini memberikan pemahaman bahwa rerata minat mempelajari bahasa Arab siswa kelas X Madrasah Aliyah Muhammadiyah Sulit Air tergolong kepada klasifikasi Baik. 
Hasil klasifikasi dan kategorisasi minat mempelajari bahasa Arab sebagaimana yang telah dijelaskan dapat digambarkan pada histogram:

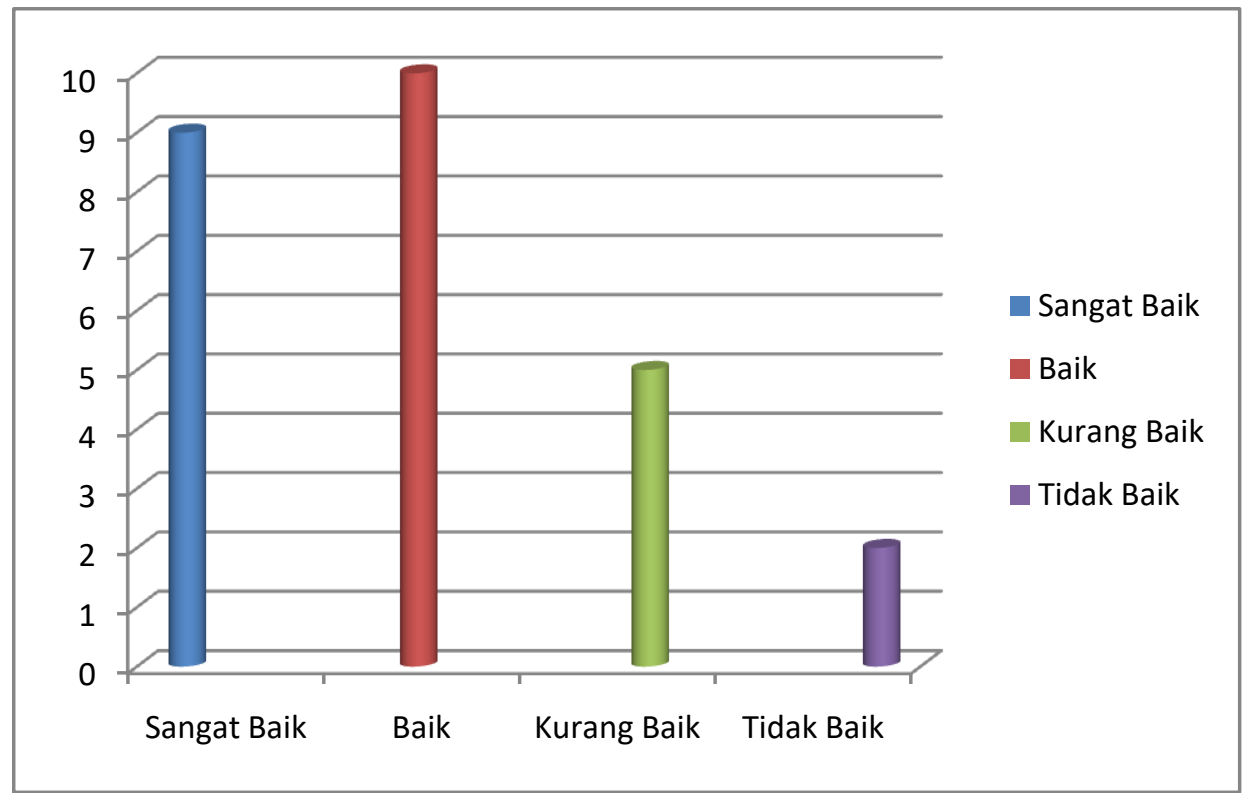

Gambar 2. Histogram Minat Mempelajari Bahasa Arab

Uraian data tentang variabel $\mathrm{Y}$ sebagaimana yang sudah dijelaskan memberikan pemahaman bahwa minat siswa kelas $\mathrm{X}$ tergolong baik dalam mempelajari bahasa Arab. Kemudian dilakukan analisis data menggunakan rumus regresi linear sederbana denganbantuan program SPSS versi 24.

\section{Uji Validitas}

Langkah ini dilakukan untuk mengukur tingkat kevalidan yang didapat dari sebaran kuesioner. Pertanyaan dan pernyataan yang dituangkan dalam angket berkaitan dengan cakupan aspek-aspek yang ingin ukur kevalidannya. Setelah dilakukan uji coba. Kemudian dianalisis menggunakan SPSS versi 24 diperoleh semua data kuisioner valid. Hasil uji validitas tersebut dapat dituangkan dalam tabel 3:

Tabel 3. Hasil Uji Validaitas

\begin{tabular}{|c|c|c|c|}
\hline $\mathrm{X}$ & Pearson Correlation & Sig. (2-tailed) & Keterangan \\
\hline $\mathrm{x} 1$ &, $528^{*}$ & 0.043 & $\mathrm{~V}$ \\
\hline $\mathrm{x} 2$ &, $517^{*}$ & 0.038 & $\mathrm{~V}$ \\
\hline $\mathrm{x} 3$ &, $630^{*}$ & 0.052 & $\mathrm{~V}$ \\
\hline $\mathrm{x} 4$ &, $543^{*}$ & 0.049 & $\mathrm{~V}$ \\
\hline $\mathrm{x} 5$ &, $529^{*}$ & 0.044 & $\mathrm{~V}$ \\
\hline
\end{tabular}




\begin{tabular}{|c|l|l|l|}
$\mathrm{x} 6$ &, $632^{*}$ & 0.054 & $\mathrm{~V}$ \\
\hline $\mathrm{x} 7$ &, $630^{*}$ & 0.052 & $\mathrm{~V}$ \\
\hline $\mathrm{x} 8$ &, $527^{*}$ & 0.041 & $\mathrm{~V}$ \\
\hline $\mathrm{x} 9$ &, $515^{*}$ & 0.034 & $\mathrm{~V}$ \\
\hline $\mathrm{x} 10$ &, $635^{*}$ & 0.057 & $\mathrm{~V}$ \\
\hline $\mathrm{x} 11$ &, $519^{*}$ & 0.400 & $\mathrm{~V}$ \\
\hline $\mathrm{x} 12$ &, $614^{*}$ & 0.032 & $\mathrm{~V}$ \\
\hline $\mathrm{x} 13$ &, $525^{*}$ & 0.045 & $\mathrm{~V}$ \\
\hline $\mathrm{x} 14$ &, $523^{*}$ & 0.042 & $\mathrm{~V}$ \\
\hline $\mathrm{x} 15$ &, $528^{*}$ & 0.043 & $\mathrm{~V}$ \\
\hline $\mathrm{x} 16$ &, $620^{*}$ & 0,039 & $\mathrm{~V}$ \\
\hline $\mathrm{x} 17$ &, $627^{*}$ & 0,051 & $\mathrm{~V}$ \\
\hline $\mathrm{x} 18$ &, $618^{*}$ & 0,037 & $\mathrm{~V}$ \\
\hline $\mathrm{x} 19$ &, $529^{*}$ & 0,044 & $\mathrm{~V}$ \\
\hline $\mathrm{x} 20$ &, $624^{*}$ & 0,50 & $\mathrm{~V}$ \\
\hline
\end{tabular}

\section{Uji reliabilitas}

Penggunaan langkah ini bermaksud untuk mengetahui kestabilan konsistensi data yang diperoleh.

\begin{tabular}{c|c}
\multicolumn{2}{c}{$\begin{array}{c}\text { Tabel } \\
\text { Reliability Statistics } \\
\text { Relil uji Reabilitas } \\
\text { Cronbach's Alpha }\end{array}$} \\
\hline, 614 & N of Items \\
\hline
\end{tabular}

\section{Uji Normalitas}

Dalam upaya mendapatkan data Untuk langkah ini peneliti menggunakan bantuan program SPSS versi 24. Dari hasil uji normalitas yang telah dilakukan diketahui bahwa nilai sig pada kolom penggunaan powerpoint yaitu 0,032. Jika dibandingkan dengan nilai Alfha maka nilai sig < dari alfha maka data tidak normal. Sedangkan untuk minat belajar bahasa Arab nilai sig didapatkan sebesar 0,200. Dengan begitu perolehan sig > Alfha maka data normal. Hasil uji normalitas sebagaimana yang ditemukan ialah dapat dituangkan dalam tabel 5 .

Tabel 5. Hasil Uji Normalitas

\begin{tabular}{|l|l|c|c|}
\hline \multicolumn{3}{|c|}{ One-Sample Kolmogorov-Smirnov Test } \\
\hline \multicolumn{2}{|c|}{} & $\begin{array}{l}\text { Penggunaan } \\
\text { Powerpoint }\end{array}$ & Minat Belajar \\
\hline N & 26 & 26 \\
\hline $\begin{array}{l}\text { Normal } \\
\text { Parameters }\end{array}$ & Mean & 82,38 & 61,73 \\
\cline { 3 - 4 } & Std. Deviation & 7,900 & 8,897 \\
\hline Most Extreme & Absolute &, 179 &, 083 \\
\hline
\end{tabular}




\begin{tabular}{|c|c|c|c|}
\hline \multirow[t]{2}{*}{ Differences } & Positive & 137 & 078 \\
\hline & Negative &,- 179 &,- 083 \\
\hline \multicolumn{2}{|l|}{ Test Statistic } & 179 & 083 \\
\hline \multicolumn{2}{|c|}{ Asymp. Sig. (2-tailed) } &, $032^{\mathrm{c}}$ & $200^{\mathrm{c}, \mathrm{d}}$ \\
\hline \multicolumn{4}{|c|}{ a. Test distribution is Normal. } \\
\hline \multicolumn{4}{|c|}{ b. Calculated from data. } \\
\hline \multicolumn{4}{|c|}{ c. Lilliefors Significance Correction. } \\
\hline \multicolumn{4}{|c|}{ d. This is a lower bound of the true significance. } \\
\hline
\end{tabular}

\section{Uji Homogenitas}

Uji homogenitas dilakukan atas bantuan program SPSS versi 24 dengan N 26. Dengan ketentuan nilai sig yang diperoleh lebih besar dari alfha 0,05 maka data yang diperoleh normal dan sebaliknya jika nilai sig lebih kecil dari alfha 0,05 berarti data yang diperoleh tidak normal. Nilai sig yang diperoleh adalah sebesar 0,820. Jika dibandingkan dengan nilai Alfha maka nilai sig $>$ dari alfha maka dapat disimpulkan bahwa data homogen atau memiliki kesamaan. Untuk lebih jelasnya dapat dilihat pada tabel berikut:

Tabel 6. Hasil uji homogenitas

\begin{tabular}{|c|c|c|c|}
\hline \multicolumn{4}{|c|}{ Test of Homogeneity of Variances } \\
\hline Minat Belajar & & & \\
\hline Levene Statistic & df1 & df2 & Sig. \\
\hline 431 & 5 & 17 & 820 \\
\hline
\end{tabular}

\section{Uji Hipotesis}

Hipotesis yang akan diuji pada penelitian ini berbunyi:

$\mathrm{Ha}$ : Terdapat pengaruh penggunaan media powerpoint terhadap minat belajar bahasa Arab siswa kelas X Madrasah Aliyah Muhammadiyah Sulit Air

Ho : Tidak Terdapat pengaruh penggunaan media powerpoint terhadap minat mempelari bahasa Arab siswa kelas X Madrasah Aliyah Muhammadiyah Sulit Air

Tabel 7. Hasil uji hipotesis

\begin{tabular}{|c|c|c|c|c|c|c|}
\hline \multicolumn{7}{|c|}{ Coefficients $^{a}$} \\
\hline \multirow{2}{*}{\multicolumn{2}{|c|}{ Model }} & \multicolumn{2}{|c|}{$\begin{array}{l}\text { Unstandardized } \\
\text { Coefficients }\end{array}$} & \multirow{2}{*}{\begin{tabular}{|c} 
Standardized \\
Coefficients
\end{tabular}} & \multirow[b]{2}{*}{$\mathrm{t}$} & \multirow[b]{2}{*}{ Sig. } \\
\hline & & B & Std. Error & & & \\
\hline \multirow[t]{2}{*}{1} & (Constant) & 14,697 & 16,399 & & 896 & ,379 \\
\hline & $\begin{array}{l}\text { Penggunaan } \\
\text { Powerpoint }\end{array}$ & ,571 & ,198 & ,507 & 2,881 & ,008 \\
\hline
\end{tabular}


Berdasarkan perhitungan diatas, dapat diungkapkan penggunaan media power poin memiliki pengaruh yang signifikan terhadap minat siswa dalam mempelajari bahasa Arab. Artinya Ho yang berbunyi "Tidak terdapat pengaruh penggunaan media powerpoint terhadap minat siswa mempelajari bahasa Arab" ditolak. Hal ini mengindikasikan bahwa hipotesis $(\mathrm{Ha})$ yang berbunyi "Terdapat pengaruh penggunaan media powerpoint terhadap minat mempelajari bahasa Arab" diterima.

\begin{tabular}{|c|c|c|c|c|}
\hline \multicolumn{5}{|c|}{ Model Summary } \\
\hline Model & $\mathrm{R}$ & R Square & $\begin{array}{l}\text { Adjusted R } \\
\text { Square }\end{array}$ & $\begin{array}{l}\text { Std. Error of } \\
\text { the Estimate }\end{array}$ \\
\hline 1 & $507^{\mathrm{a}}$ & 257 & .226 & 7,828 \\
\hline
\end{tabular}

Besaran pengaruh media power poin terhadap minat mempelajari bahasa Arab diketahui dari nilai Rsquare X100 \%. Maka 0,257X100\% $=25,7 \%$ besar pengaruh penggunaan powerpoint terhadap minat belajar bahasa arab siswa, sedangkan 74,3\% lagi dipengaruhi oleh faktor belajar lainnya.

Hasil analisis di atas sesuai dengan kesimpulan Azhari yang menyatakan bahwa media pembelajaran memiliki peran penting dalam meningkatkan kemampuan bahasa Arab, hasil ini juga mendukung kesimpulan Nurhidayati yang menegaskan bahwa power point yang didesain dengan baik akan memberikan pengaruh terhadap kualitas proses dan hasil belajar bahasa Arab. Kesesuaian hasil penelitian ini dengan kesimpulan para peneliti terdahulu mengisyaratkan bahwa guru bahasa Arab harus melakukan inovasi dalam pembelajaran dengan mempertimbangkan perkembangan teknologi yang sudah akrab dengan siswa.

\section{Penutup}

Hasil penelitian serta pembahasan yang diungkapkan dapat disimpulkan: pertama, Penggunaan media powerpoint dilihat dari nilai evaluasi siswa tergolong kepada klasifikasi tinggi, yang dibuktikan dengan nilai tengah 82,5. Perolehan ini ketika dikembalikan pada kategori yang terdapat dalam interval penggunaan powerpoint tergolong kepada klasifikasi tinggi yaitu berkisar pada interval 82-88. Kedua, minat mempelajari bahasa Arab sesuai dengan data kuisioner responden tergolong pada klasifikasi baik, pernyataan ini didasarkan pada perolehan mean sebesar 61,7. Harga ini ketika dikonversikan pada klasifikasi minat maka data berada pada kategori baik, yaitu berada pada interval 58-66. Ketiga, penggunaan media power point mempengaruhi minat mempelajari bahasa Arab. Bisa dilihat pada uji hipotesis diperoleh nilai sig 0,008 sedangkan taraf signifikan alfha 0,05. Jadi nilai sig lebih kecil dari alfha. 


\section{Bibliografi}

Al-Busaidi, Fatma Y., 'Arabic in Foreign Language Programmes: Difficulties and Challenges', Journal of Educational and Psychological Studies [JEPS], 9 (2015), 701-17 <https://doi.org/10.24200/jeps.vol9iss4pp701-717>

Arifin, Ahmad, 'Peranan Permainan Bahasa Dalam Proses Kegiatan Belajar Mengajar Mata Pelajaran Bahasa Arab', Jurnal An Nabighoh, 19 (2017), 30218

Azhari, Azhari, 'Peran Media Pendidikan Dalam Meningkatkan Kemampuan Bahasa Arab Siswa Madrasah', Jurnal Ilmiah Didaktika, 16 (2015), 43-60 <https://doi.org/10.22373/jid.v16i1.586>

Karaghanh, Jawad, Ismail Nadri, Ibrahim Namdari, Mehdi Dawri Dultabad, and Faridoun Ramdani, 'Al-'Alaqah Bayn Hafiz Al-Ta'allum Wa Maharah AlMuhadatsah Min Khilal Al-Taqyim Al-Dzaty Li Mudarris Al-Lughah Al'Arabiyyah', Majallah Kulliyah Al-Tarbiyyah Al-Asasiyyah Li Al-'Ulum AlTarbawiyyah Wa Al-Insaniyyah, 43 (2019), 754-64

Kurnia, Nia, Deni Darmawan, and Maskur Maskur, 'Efektivitas Pemanfaatan Multimedia Pembelajaran Berbantuan Ispring Dalam Meningkatkan Motivasi Dan Hasil Belajar Pada Mata Pelajaran Bahasa Arab', Teknologi Pembelajaran, 3 (2018), 451-61 < https://doi.org/10.31980/TP.V3I1.158>

Laraswati, Iranada, and Suhartono, 'The Use of Visual Media in Teaching Writing', English-EDU Journal of English Teaching and Research, 1 (2016), 3743

Mahmudah, Siti, 'Media Pembelajaran Bahasa Arab', An Nabighob Jurnal Pendidikan Dan Pembelajaran Bahasa Arab, 20 (2018), 129-38 <https://doi.org/10.32332/an-nabighoh.v20i01.1131>

Maimunah, Vivi, Zaim El Mubarok, and Ahmad Miftahuddin, 'KIA (Kitabah Itu Asyik): Pengembangan Multimedia Berbasis Adobe Falsh Professional CS6 Pada Keterampilan Menulis Untuk Siswa Kelas X MA', LISANUL ARAB Journal of Arabic Learning and Teaching, 7 (2018), 54-62

Mohammad Nasrullah, Yufi, 'Atsar Istikhdam Al-Wasa'il Al-Ta'limiyyah Fi Ta'lim Al-Lughah Al-'Arabiyyah Fi Jami'ah Indunisiya Al-Tarbawiyyah Bi Jazirah Jawa Al-Ghorbiyyah', Jurnal Al-Bayan, 9 (2017), 17-30

Nugrawiyati, Jepri, 'Media Audio-Visual Dalam Pembelajaran Bahasa Arab', ElWasathiya: Jurnal Studi Agama, 6 (2018), 96-111 < https://doi.org/10.24090/insania.v14i3.360>

Nurhidayati, 'Media Power Point Dan Pemanfaatannya Dalam Proses Pembelajaran Bahasa Arab', in Konferensi Nasional Bahasa Arab V, 2019, LIII, 463-70 
Purwanto, Nanang Joko, 'Lagu Sebagai Media Pembelajaran Tata Bahasa Arab (Nahwu)', Maharat: Jurnal Pendidikan Bahasa Arab, 1 (2018), 1-13 <https://doi.org/10.18196/mht.111>

Rusady, Achmad Tito, 'Dawafi' Al-Thullab Fi Ta'allum Al-Lughah Al'Arabiyyah Wa Dawr Al-Mu'allim Fi Tarqiyatiha', Jurnal Izdihar: Journal of Arabic Language Teaching, Linguistics, and Literature, 1 (2018), 65-78

Samiyah, Numr, 'Dawr Al-Wasa'il Al-Ta'limiyyah Al-Haditsah Fi Tahsin Naw'iyah Al-Ta'lim Bi Al-Marhalah Al-Tsanawiyyah' (Jami'ah al-'Araby bin Mahidy, 2015)

Shodiq, Muhammad Jafar, 'Metode Pembeelajaran Bahasa Arab Aktif-Inovatif Berbasis Multiple Intelligences', Al Mahara Jumal Pendidikan Bahasa Arab, 4 (2018), $125-48$ <https://doi.org/10.1093/gao/9781884446054.article.t060170>

Suardipa, I Putu, 'Guru Sebagai Agen Inovator Berbasis Higher Order Thinking Skills', Purwadita: Jurnal Agama Dan Budaya, 2 (2018), 73-83

Syarifuddin, and Muadip, 'Pengaruh Penggunaan Media Audio Visual Terhadap Hasil Belajar Siswa Kelas X Bahasa SMA Al-Ashriyyah Nurul Iman Parung-Bogor', Jurnal Educate, 1 (2016), 77-102

Uliyah, Asnul, and Zakiyah Isnawati, 'Metode Permainan Edukatif Dalam Pembelajaran Bahasa Arab', Shaut Al-'Arabiyah, 7 (2019), 31-43 $<$ https://doi.org/10.24252/saa.v1i1.9375>

Zulhannan, Teknik Pembelajaran Bahasa Arab Interaktif (Jakarta: PT. Raja Grafindo, 2014) 
192 | Arabiyatuna : Jurnal Bahasa Arab, Vol. 4, No. 1, 2020

HALAMAN INI SENGAJA DIKOSONGKAN 